\title{
"Study of the Effects of lateral Substitution (Bromo) on Mesomorphic Behaviours of Chalconyl Ester Derivatives"
}

\author{
Ravindra Solanki ${ }^{1}$ and R.B Patel ${ }^{*}$, \\ Chemistry Department, \\ K.K. Shah Jarodwala Maninagar Science College, \\ Gujarat University, Ahmedabad-8, Gujarat -India. \\ Email id of Corresponding author: \\ 1: ravindrasolanki19@gmail.com, \\ *: roshanpatel770@gmail.com
}

Keywords: Liquid Crystal, Lateral Substitution, Nematic, Smectic, Enantiotropy.

\begin{abstract}
Novel homologous series: $\mathrm{RO}-\mathrm{C}_{6} \mathrm{H}_{4}-\mathrm{COO}-\mathrm{C}_{6} \mathrm{H}_{3}-\mathrm{Br}-\mathrm{CO}-\mathrm{CH}=\mathrm{CH}-\mathrm{C}_{6} \mathrm{H}_{4}-\mathrm{OC}_{18} \mathrm{H}_{3}$ (n) (ortho bromo to - COO-) is synthesized and studied with a view to understand and establish the relation between mesomorphic properties and the molecular structure with reference to lateral substitution of bromine

$-\mathrm{Br}$ at middle phenyl ring. Chalconyl homologous series consists of thirteen homologues between $\left(\mathrm{C}_{1}\right.$ to $\left.\mathrm{C}_{18}\right)$. Nematogenic mesomorphism commences from $\mathrm{C}_{5}$ homologue and continues up to $\mathrm{C}_{18}$ homologue in enantiotropic manner. Transition and melting points were determined by an optical polarizing microscopy (POM) equipped with a heating stage. Textures of nematic phase are threaded or schlieren. Transition curve $\mathrm{Cr}-\mathrm{N} / \mathrm{I}$ behaved in normal manner. N-I transition curve exhibited odd-even effect up to $\mathrm{C}_{8}$ homologue. It (N-I) rises and fall with negligible deviations from its normal descending tendency which appears in case of homologues $\mathrm{C}_{10}$ to $\mathrm{C}_{18}$. Thermal stability for nematic is $142.89{ }^{\circ} \mathrm{C}$ and the mesophase lengths vary minimum $8.0^{\circ} \mathrm{C}$ to maximum $26.0^{\circ} \mathrm{C}$ at the $\mathrm{C}_{7}$ and $\mathrm{C}_{8}$ homologue respectively. Liquid Crystal properties of present series are evaluated and compared with structurally analogous series and relative group efficiency order derived. Thus, present series is predominantly nematogenic with absence of Smectic property. Analytical and spectral data supported moleculars of homologues.
\end{abstract}

\section{Introduction:}

Thermotropic liquid crystal (LC) of chalconyl ester with long n- alkoxy chain as tail end group [1] have been proposed to synthesize and study, because of their dual importance to act as LC material and potentiality as to act as anti- malarial, anti- cancer, anti- bacterial, anti- oxidant etc. $[2,3,4,5,6,7]$. Present proposed investigation is planned with a view to understand and establish the effect of molecular structure on thermo tropic LC properties $[8,9,10,11]$ of laterally substituted $\mathrm{Br}$ group at the middle phenyl ring as a consequence of molecular rigidity and flexibility $[12,13,14,15]$. Number of chalconyl ester homologous series have been reported till the date $[16,17,18,19,20,21,22,23]$. The properties of proposed series of novel chalconyl derivatives will be compared with other known series and the group efficiency order will be derived. Novel substance may be useful for the scientists and technologist who are working on LC state with different aims and objects other than present object to extend or to continue their research in the benefit of mankind and societies.

\section{Experimental:}

\section{Synthesis:}

4-Hydroxy benzoic acid was alkylated using suitable alkylating agent (R-X) to convert it into 4n-alkoxy benzoic acids (A) by modified method of Dave and Vora [24], $\alpha-3-$ Bromo -4 Hydroxy benzoyl $\beta-4$ '- n-octadecyloxy phenyl ethylene (B) was prepared by usual established method [25]. 4-n-Alkoxy benzoic acids and $\alpha-3$ - Bromo -4 Hydroxy benzoyl $\beta-4$ - n-Octadecyloxy phenyl 
ethylene were condensed in 1, 3-dicyclohexylcarbodiimide (DCC), 4-dimethyl amino pyridine (DMAP) and $\mathrm{CH}_{2} \mathrm{Cl}_{2}$ [26] to obtain $\alpha-4-\left(4^{\prime}-n-A l k o x y\right.$ benzoyloxy) benzoyl- $\beta-4$ " -n- Octadecyloxy 3 - bromo phenyl phenyl ethylene. Final products were filtered, washed, dried and purified till the constant transition temperatures obtained. The synthetic route to the novel homologous series of ethylene derivatives is under mentioned in scheme- 1 .

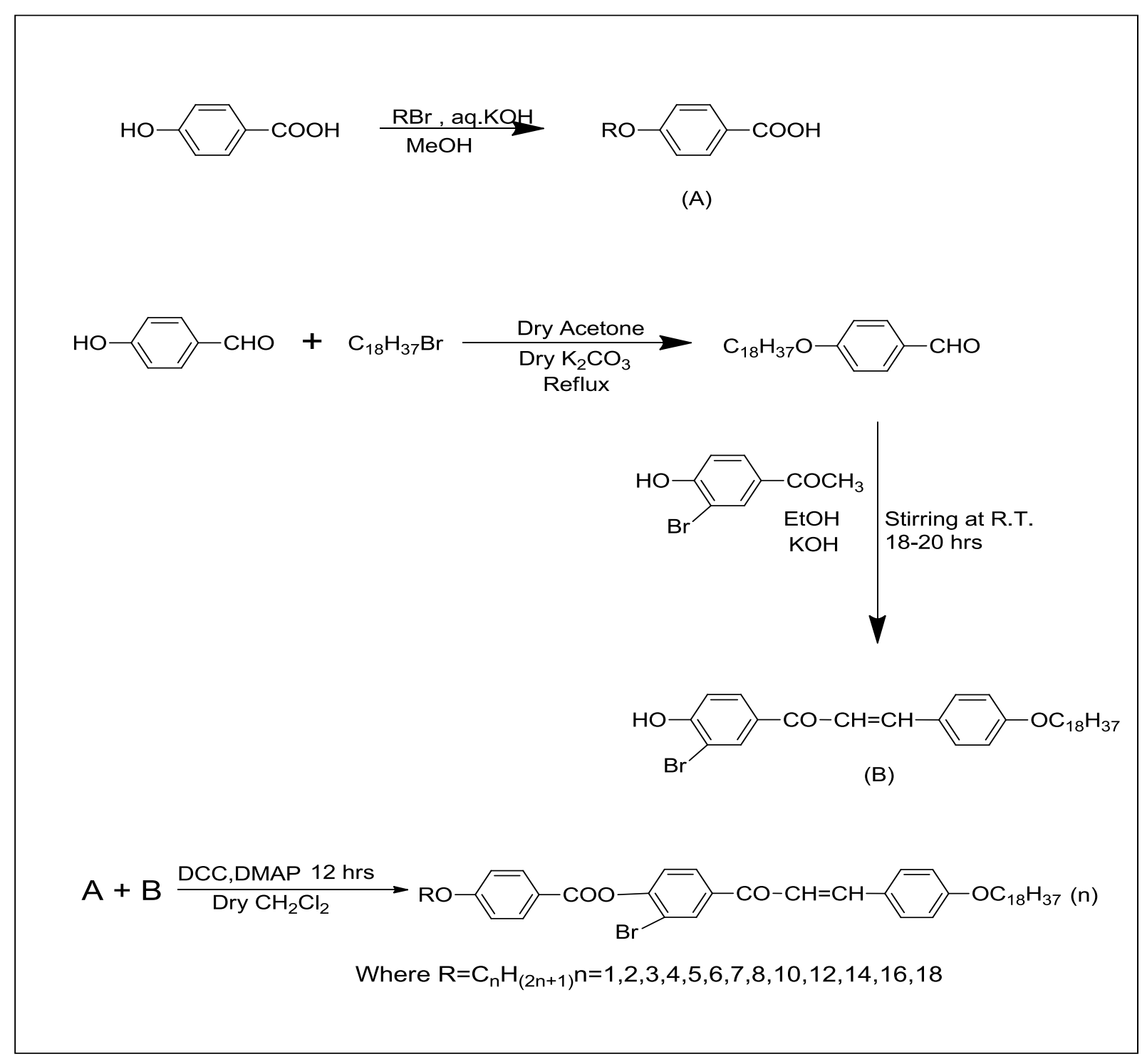

Scheme 1:-Synthetic route to the series

\section{Characterization:}

Representative homologues of a series were characterized by elemental analysis, Infra red spectroscopy, ${ }^{1} \mathrm{H}$ NMR spectra, IR spectra were recorded by Perkin-Elmer spectrum GX, ${ }^{1} \mathrm{H}$ NMR spectra were recorded on Bruker using $\mathrm{CDCl}_{3}$ as solvent. Microanalysis was performed on PerkinElmer PE $2400 \mathrm{CHN}$ analyser (Table-1). Transition temperature and LC properties (Textures) were determined using an optical polarising microscopy equipped with heating stage. Textures of nematic phase determined by miscibility method (Table-2) thermodynamic quantities enthalpy $(\Delta \mathrm{H})$ and entropy $(\Delta \mathrm{S}=\Delta \mathrm{H} / \mathrm{T})$ are qualitatively discussed. 


\section{Analytical data:}

Table 1: Elemental analysis for Ethoxy, Pentyloxy, Decyloxy, Dodecyloxy derivatives.

\begin{tabular}{|c|c|c|c|c|c|c|c|}
\hline \multirow{2}{*}{ Sr. No. } & Molecular formula & \multicolumn{4}{|c|}{ Elements found \% } & \multicolumn{3}{c|}{ Elements calculated \% } \\
\cline { 3 - 8 } & & $\mathbf{C}$ & $\mathbf{H}$ & $\mathbf{B r}$ & $\mathbf{C}$ & $\mathbf{H}$ & $\mathbf{B r}$ \\
\hline 1 & $\mathrm{C}_{2}$ & 70.16 & 7.8 & 11.12 & 70.07 & 7.6 & 11.12 \\
\hline 2 & $\mathrm{C}_{5}$ & 70.90 & 8.10 & 10.59 & 70.95 & 8.01 & 10.51 \\
\hline 3 & $\mathrm{C}_{10}$ & 72.00 & 8.60 & 9.8 & 72.20 & 8.5 & 9.6 \\
\hline 4 & $\mathrm{C}_{12}$ & 72.60 & 8.5 & 9.20 & 72.64 & 8.7 & 9.31 \\
\hline
\end{tabular}

IR Spectra (KBr) in $\mathrm{cm}^{-1}$ for Octyloxy, Tetra decyloxy Derivatives:

Octyloxy: 514 (-CH-Br str) ,763 Poly methylene $\left(-\mathrm{CH}_{2}-\right)$ n of $-\mathrm{OC}_{8} \mathrm{H}_{17}, 831$ ( $-\mathrm{C}-\mathrm{H}-\mathrm{def} . \mathrm{m}$ disubstituted-Para), 778 Polymethylene $\left(-\mathrm{CH}_{2}-\right)$ of $-\mathrm{OC}_{18} \mathrm{H}_{37}, 985$ (-C-H- def. hydrocarbon), 1024 and 1110(-C-O-) Str, 1253 and 1301 and 1423, 1485 (-C-O str in - $\left(\mathrm{CH}_{2}\right)$ n chain), 1508 (-C-H- def. in $\left.\mathrm{CH}_{2}\right), 1575$ ( $-\mathrm{C}=\mathrm{C}-$-)str, 1602 (-C=O group), 1743 (-COO- ester group), 2852 and 2923 and 3064 (-C-H str in $\mathrm{CH}_{3}$ ).

Tetradecyloxy: 518 and 675 (-CH-Br str), 722 and762 Polymethylene $\left(-\mathrm{CH}_{2}-\right)$ n of $-\mathrm{OC}_{14} \mathrm{H}_{29}, 835$ and 850( $-\mathrm{C}-\mathrm{H}$ - def. $\mathrm{m}$ di-substituted-Para) Benzene ,989 (-C-H- def. hydrocarbon), 1027, 1074,1114, 1172 (-C-O-) Str, of $\mathrm{C}_{18} \mathrm{H}_{37}, 1384$ and 1321 and 1303, 1257 ( $-\mathrm{C}-\mathrm{O}$ str in $-\left(\mathrm{CH}_{2}\right)$ n chain, 1481 (-C-H- def. in $\mathrm{CH}_{2}$ ), 1512 and 1581 ( $-\mathrm{C}=\mathrm{C}-$ )str, 1606 and 1616 (-C=O group), 1730 (-COOester group), 2858 and 2927 and 3033 (-C-H str in $\mathrm{CH} 3$ ).

${ }^{1} \mathrm{H}$ NMR spectra in $\mathrm{CDCl}_{3}$ in $\delta$ ppm for Pentyloxy \& Hexyloxy Derivative:

Pentyloxy: $0.90\left(\mathrm{t},-\mathrm{CH}_{3}\right.$ of $\left.-\mathrm{C}_{5} \mathrm{H}_{11}\right), 1.31-1.76\left(\mathrm{~m}\right.$, n-poly methylene groups of- $\left.\mathrm{OC}_{5} \mathrm{H}_{11}\right), 1.55-1.76$ (m, n-poly methylene groups of $\left.-\mathrm{OC}_{18} \mathrm{H}_{37}\right), 4.10-4.20\left(\mathrm{~s},-\mathrm{OCH}_{2}-\mathrm{CH}_{2}-\mathrm{ofOC}_{18} \mathrm{H}_{37}\right), 4.0-4.2\left(\mathrm{~s},-\mathrm{OCH}_{2}-\right.$ $\mathrm{CH}_{2}$-of $\left.\mathrm{OC}_{5} \mathrm{H}_{11}\right), 7.58$ and 8.20(s,-CO-CH=CH),8.8-8.9 (s, p-di substituted phenyl ring).

Hexyloxy:0.88( $\mathrm{t},-\mathrm{CH}_{3}$ of $\left.-\mathrm{C}_{6} \mathrm{H}_{13}\right), 1.3-1.43\left(\mathrm{~m}, \mathrm{n}\right.$-poly methylene groups of $\left.-\mathrm{OC}_{18} \mathrm{H}_{37}\right), 1.5-1.7(\mathrm{~m}$, n-poly methylene groups of- $\left.\mathrm{OC}_{6} \mathrm{H}_{13}\right), 4.1\left(\mathrm{~s},-\mathrm{OCH}_{2}-\mathrm{CH}_{2}\right.$-of $\left.\mathrm{OC}_{6} \mathrm{H}_{13}\right), 4.1-4.4\left(\mathrm{~s},-\mathrm{OCH}_{2}-\mathrm{CH}_{2}\right.$-of $\left.\mathrm{OC}_{18} \mathrm{H}_{37}\right), 6.94-7.15$ (s, substituted benzene),6.9-7.2(s, - $\left.\mathrm{CO}-\mathrm{CH}=\mathrm{CH}\right), 7.5-7.7(\mathrm{~s}, \mathrm{p}$-substituted phenyl ring).

Table 2: Textures of Nematic phase by miscibility method for $C_{7}, C_{10}, C_{16}, C_{18}$.

\begin{tabular}{|c|c|c|}
\hline Sr. No. & Homologue & Texture \\
\hline 1 & $\mathrm{C}_{7}$ & Threaded \\
\hline 2 & $\mathrm{C}_{10}$ & Threaded \\
\hline 3 & $\mathrm{C}_{16}$ & Schlieren \\
\hline 4 & $\mathrm{C}_{18}$ & Schlieren \\
\hline
\end{tabular}

\section{Results and Discussion:}

$\alpha$-3- Bromo -4- hydroxyl benzoyl - $\beta$ - $4 ` \mathrm{n}$ - octadecyloxy phenyl ethylene (m.p- $85{ }^{\circ} \mathrm{C}$, yield-74 $\%)$ is a nonmesomorphic component, which on condensation with dimaric n- alkoxy benzoic acid yielded mesomorphic homologues from $\mathrm{C}_{5}$ to $\mathrm{C}_{18}$ as enantiotropically nematogenic without exhibition of smectogenic property. The transition temperatures as determined using an optical polarizing microscopy equipped with a heating stage of mesogenic homologues are relatively lower than the corresponding n- alkoxy acids. Transition curves Cr-N/I and N-I showing the phase behaviours of novel series in a phase diagram (figure.1) are obtained by linking points plotted for the number of carbon atoms present in $n$ - alkyl ' $\mathrm{R}$ ' chain of left -OR group versus the transition temperatures as recorded in table - 3 
Table 3: Transition Temperatures in ${ }^{\circ} \mathrm{C}$ for Homologous series:

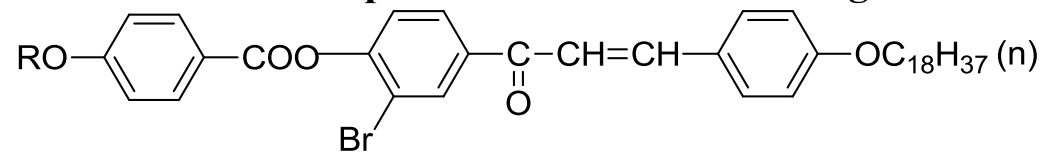

Homologous series: $\alpha-4-\left(4^{\prime}-n-A l k o x y\right.$ benzoyloxy) benzoyl- $\beta-4$ “ -n- octadecyloxy 3 - bromo phenyl ethylene.

\begin{tabular}{|l|l|l|l|l|}
\hline $\begin{array}{l}\text { Compound } \\
\text { No }\end{array}$ & n-alkyl chain $\mathrm{C}_{\mathrm{n}} \mathrm{H}_{2 \mathrm{n}+1}$ & \multicolumn{4}{l}{ Transition Temperatures in $\left({ }^{\circ} \mathrm{C}\right)$} \\
\hline & & Smectic & Nematic & Isotropic \\
\hline 1 & $\mathrm{C}_{1}$ & - & - & 170.0 \\
\hline 2 & $\mathrm{C}_{2}$ & - & - & 185.0 \\
\hline 3 & $\mathrm{C}_{3}$ & - & - & 158.0 \\
\hline 4 & $\mathrm{C}_{4}$ & - & - & 152.0 \\
\hline 5 & $\mathrm{C}_{5}$ & - & & \\
& & & 118.0 & 138.0 \\
\hline 6 & $\mathrm{C}_{6}$ & - & 130.0 & 148.0 \\
\hline 7 & $\mathrm{C}_{7}$ & - & 132.0 & 140.0 \\
\hline 8 & $\mathrm{C}_{8}$ & - & 128.0 & 138.0 \\
\hline 9 & $\mathrm{C}_{10}$ & - & 131.0 & 148.0 \\
\hline 10 & $\mathrm{C}_{12}$ & - & 128.0 & 143.0 \\
\hline 11 & $\mathrm{C}_{14}$ & - & 134.0 & 152.0 \\
\hline 12 & $\mathrm{C}_{16}$ & - & 140.0 & 155.0 \\
\hline 13 & $\mathrm{C}_{18}$ & - & 98.0 & 124.0 \\
\hline
\end{tabular}

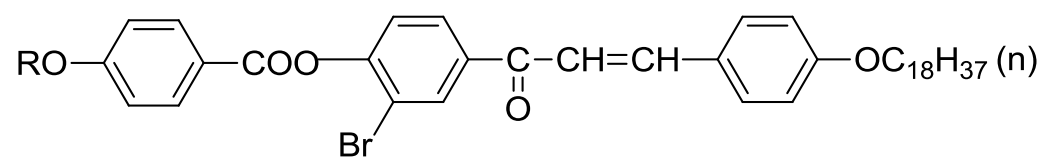

Homologous series: $\alpha-4-(4$ '-n-Alkoxy benzoyloxy) benzoyl- $\beta-4$ " $-n$ - octadecyloxy 3- bromo phenyl ethylene. 


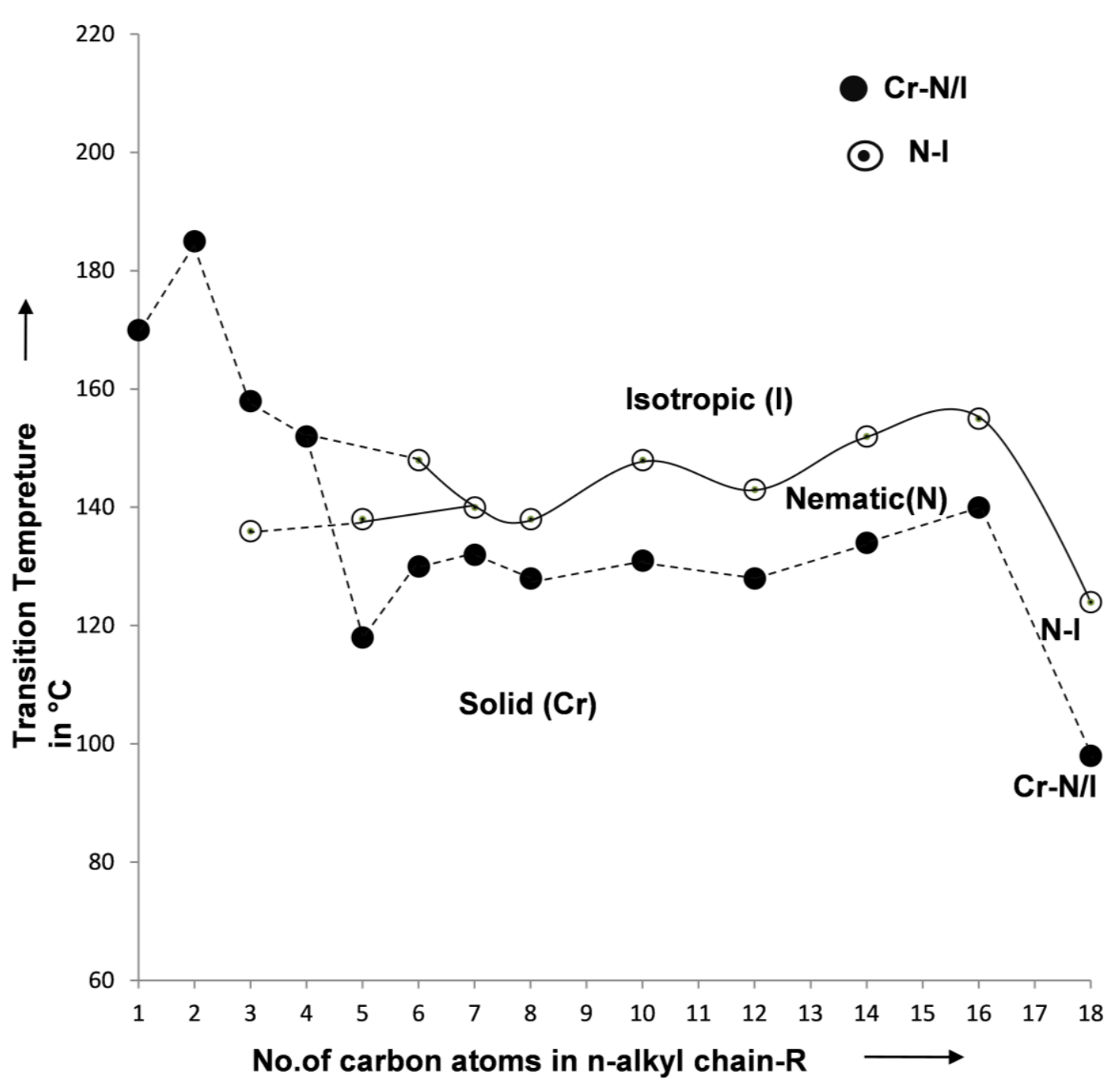

Figure 1: Phase behavior of the series

The Cr-N/I transition curve adopted a zig-zag path of rising and falling and finally descended in normal manner. N-I transition curve exhibited odd even effect from $\mathrm{C}_{5}$ to $\mathrm{C}_{8}$ homologue with merging of N-I transition curves at $\mathrm{C}_{8}$ homologue. Then N-I transition curve negligibly rises and falls with overall normal descending tendency of negligible rising abnormality transition curves for odd and even members are extrapolated to $\mathrm{C}_{4}$ and $\mathrm{C}_{3}$ homologues to highlight the odd-even effect and to predict their nematogenic transition temperatures [27,28,29,30].N-I transition curve prolong as a single transition curve from and beyond merging of transition curve showing odd - even effect upto $\mathrm{C}_{8}$ homologue for longer $n-$ alkyl chain $\left(\mathrm{R}^{\prime}\right)$ of $-\mathrm{OR}$. Thermal stability for nematic is 142.89 ${ }^{\circ} \mathrm{C}$ and mesomorphase length lower to upper varies from 8.0 to $26.0{ }^{\circ} \mathrm{C}$ at the $\mathrm{C}_{7}$ and $\mathrm{C}_{18}$ homologues. It is middle order melting type series. Textures of a nematic phase are threaded or schlieren. Mesomorphic properties from homologue to homologue varies with varying number of carbon atoms in n- alkyl chain ' $\mathrm{R}$ ' of -OR keeping - $\mathrm{OC}_{18} \mathrm{H}_{37}$ (n) tail end group unchanged. Mesogenic behaviors of present series are compared with structurally analogous series to derive group efficiency order as depended on molecular structure as a consequence of resulted molecular rigidity and flexibility. The absence of mesomorphic behaviours of $\mathrm{C}_{1}$ to $\mathrm{C}_{4}$ homologues is due to their high crystallizing tendency which arises from low magnitude of dispersion forces and the dipole dipole interaction, which causes unsuitable magnitude of anisotropic forces of intermolecular cohesion and closeness. Laterally substituted polarizable $-\mathrm{Br}$ group, which increases intermolecular distance and decrease intermolecular attractive forces but at the same time the molecular polarizability increases intermolecular cohesion, Therefore, two opposing forces which are operated for the same reason of lateral substitution. Thus, resultant effect which will be operative of suitable 
magnitudes will depend upon the predominantly of the factor (closeness or polarizability) operating in opposite direction for the same reason which facilitated nematic phase. The exhibition of nematogenic mesophase formation by $\mathrm{C}_{5}$ to $\mathrm{C}_{18}$ homologues is attributed to the intermolecular suitable forces of end to end and lateral cohesion and closeness as a consequence of favorable molecular rigidity and flexibility as depended molecular structure, which facilitated and maintained floating of molecules of $\mathrm{C}_{5}$ to $\mathrm{C}_{18}$ homologues on the surface as statistically parallel orientational order for some degree of temperature difference, causing appearance of nematic phase. In exhibition of smectic mesophase formation is attributed to the absence of sliding layer molecular arrangement in floated condition under exposed thermal vibrations due to unsuitable magnitude of intermolecular lateral attraction irrespective of presence of laterally substituted $-\mathrm{Br}$ functional group. The lowering of transition temperature of novel homologues as compared to corresponding $\mathrm{n}$ - alkoxy acids is attributed to breaking of hydrogen bonding through esterification process. The exhibition of odd-even effect is due to the sequentially added methylene unit or units at the nalkoxy (-OR) group. The diminishing of odd-even effect from and beyond $\mathrm{C}_{8}$ homologue is attributed to the coiling or bending or flexing or coupling of longer $n$ - alkyl chain with major axis of the core structure of a molecule of higher homologues. The negligible deviation of N-I transition curve of present series is attributed to unusual status and unusual unexpected behaviours of n-alkyl chain of ' $\mathrm{R}$ ' and $-\mathrm{C}_{18} \mathrm{H}_{37}$ end under exposed thrmal vibrations. The variation in mesogenic properties from homologue to homologue in the same series is attributed to changing number of methylene units, which causes alteration in molecular length, length to breadth ratio, permanent dipole moment across the long molecular axis magnitude of intermolecular forces of cohesion and closeness casing variation in magnitude of dispersion forces as a result of effective molecular rigidity and flexibility depending on molecular structure, its size and geometrical shape and the ratio of the polarity to polarizability.

The mesogenic behaviors of present novel series are compared with the structurally analogous series-X [31] as mention below in figure. 2 .

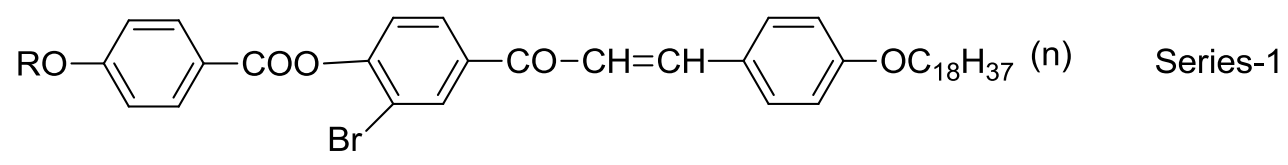

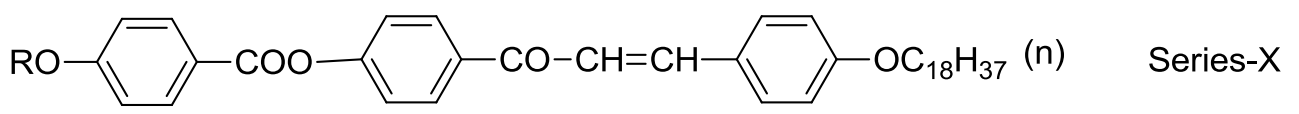

Figure:2 Structurally Similar Series

Homologous series-1 of present investigation and a homologous series- $\mathrm{X}$ selected for comparative study are identical with respect to three phenyl rings, two central bridge - COO- and $-\mathrm{CO}-\mathrm{CH}=\mathrm{CH}-$ left and right flexible terminal end group, but they differ with respect to laterally substituted $-\mathrm{Br}$ group which is present in series- 1 but is absent in series-X. Thus, the combined effect of molecular rigidity and flexibility for the same homologue from series to series and from homologue to homologue in the same series differs in magnitude. Thus, the magnitudes of mesogenic properties and the degree of mesomorphism depend upon the differing features of the molecular structures of series under comparison. Following table-4 represents the some differing features like type of mesophase exhibited commencement of mesophase, thermal stability, total mesophase lengths (lower and upper) etc as recorded below. 
Table 4: Relative thermal stability in ${ }^{\circ} \mathrm{C}$

\begin{tabular}{|c|c|c|}
\hline Series $\rightarrow$ & Series -1 & Series-X \\
\hline $\begin{array}{c}\text { Sm-I or Sm-N } \\
\text { Commencement of } \\
\text { Smectic phase }\end{array}$ & - & - \\
\hline $\begin{array}{c}\text { Nematic-isotropic } \\
\text { (N-I) } \\
\text { Commencement of } \\
\text { nematic phase }\end{array}$ & $\begin{array}{c}142.89 \\
\left(\mathrm{C}_{5}-\mathrm{C}_{18}\right) \\
\mathrm{C}_{5}\end{array}$ & $\begin{array}{c}122.0 \\
\left(\mathrm{C}_{5}-\mathrm{C}_{18}\right) \\
\mathrm{C}_{5}\end{array}$ \\
\hline $\begin{array}{l}\text { Total mesomorphism } \\
\text { in } \mathrm{C}\end{array}$ & $\begin{array}{c}08.0 \text { to } 26.0 \\
\mathrm{C}_{7} \mathrm{C}_{18}\end{array}$ & $\begin{array}{l}7.0 \text { to } 38.0 \\
\mathrm{C}_{7} \mathrm{C}_{12}\end{array}$ \\
\hline
\end{tabular}

- Homologous series 1 and $X$ under comparative study are enantiotropically nematogenic without exhibition of smectic property.

- Thermal stability for nematic is raised by 20.89 units by introduction of $-\mathrm{Br}$ lateral group at ortho position to the $-\mathrm{COO}$ - central bridge and meta position to $-\mathrm{CO}-\mathrm{CH}=\mathrm{CH}$ - group.

- The nematogenic mesophase identically commences from $\mathrm{C}_{5}$ homologue for both the series-1 and $\mathrm{X}$ under comparison.

- A total mesophase length of present series-1 is relatively lower than a series-X.

The exhibition of only nematic phase by the both series- 1 and $\mathrm{X}$ is attributed to only by end to end attraction of suitable magnitudes require for an environmental molecular arrangement under floating condition under the influence of exposed thermal vibration. The laterally substituted $-\mathrm{Br}$ group at the middle phenyl ring which should have raised intermolecular lateral attractions by operating polarizability factor more than the polarizability to be played by linear molecule of series$\mathrm{X}$. However it seems that, the reduction or decrease in intermolecular attraction by the increasing with of molecules of series- 1 is compensated through acting of polarizability factor by increasing molecular width of series-1,due to laterally substituted $-\mathrm{Br}$ group Thus , the magnitudes of intermolecular attractions by polarizable nature enhanced in case of series-1 to such an extent that it raises thermal stability for nematic by 20.89 unit as compared to the corresponding nematic thermal stability of series-X, but at the same time, the resistivity towards exposed thermal vibration undergo reduction from 7.0 to 38.0 of series- $\mathrm{X}$ to 8.0 to $26.0{ }^{\circ} \mathrm{C}$ of series- 1 under comparative study. The commencement of nematic phase which take place in series-1 and $\mathrm{X}$ in equal manner i.e. mesophase commence from $\mathrm{C}_{5}$ homologue in both series which suggest that, irrespective $-\mathrm{Br}$ lateral substitution, the molecular co planarity or non co -planarity are almost equal. i.e. presence of Bromo like lateral substitution does could not attar the extent of molecular noncoplanarity. Thus, the combined effect of molecular rigidity and flexibility in case of present series-1, is sufficient to facilitate nematic phase from $\mathrm{C}_{5}$ to $\mathrm{C}_{18}$ but the intermolecular forces of attraction are insufficient to cause lamellar packing of molecules in crystal lattice of series -1, which fails to exhibit smetogenic character. Hence, the thermal stability is raised but the upper mesophase length of series-1 is reduced, keeping commencement of mesophase unaltered from $\mathrm{C}_{5}$ homologue in case of series-1 and $\mathrm{X}$.

\section{Conclusions:}

From above result and discussion we concluded that the novel chalconyl based series only nematogenic in nature with absence of Smectogenic property. The thermal stability of series -1 is higher than the series $-X$. the lateral bromo group increasing the nematogenic properties but in novel series no homologue exist smectic properties. Mesomorphic properties of series -1 is less than the seires $-X$. 


\section{Acknowledgement}

Authors acknowledge thanks to Dr. R. R. Shah, principal of K. K. Shah Jarodwala Maninagar Science College, Ahmedabad. Authors are also thankful to Dr. A. V. Doshi, Ex-principal of M.V.M. Science \& Home Sci. College - Rajkot for his constant support, inspirations and help, as and when needed during the course of present investigation. Authors thank to NFDD Centre for the analytical and spectral services.

\section{References}

[1] F.Reinitzer,Montsh 9,421(1888).

[2] S.Narmura.Advance LCD technologies, Display 22(1)(2001)PP.1

[3] W.S.Kim,S.J.Elston and F.P.Raynes,Diplays 29 (2008).PP.458-463.

[4] Dr.L.K.Omray, current trend in tech. and sci. vol. II, Issue VI PP 347-352.

[5] Imaran Tadwee, Dr.sahanashahi, Vivek Ramtake, Iftequr Syed, Liquid Crystal Pharmaceutical Application:A review, IJRAS,ISSN2277-36.Vol.1Issue2(2012),06-11.

[6] C.A. Calliste, J.C. Le Bail, P. Trouilas, C. Poug, A.J. Chulia, L.J. Durox, Anticancer, Res.2001,21, 3949-3956.

[7] G.W.Gray, Molecular Structure and properties of Liquid crystal and plastic crystal, chepter6.2, The role of liquid crystal in life processes by G.T.Stewart, Vol -1, PP.308-326.

[8] C.T. Imrie, Liq.Crystal dimers. Struct. Bond 95(1999) PP.149-192.

[9] G.W.Gray (1974) In; G.W.Gray and P.A. Winsor (eds) Liquid crystal and Plastic Crystal, Chapter-4,Volume-1,PP-103-153.

[10] G.W.Gray and Molecular Structures and properties of liquid crystals, Academic press Landon, 1962.

[11] P.A. Henderson, O. Niemeyer, and C.T. Imrie, Methylene-linked liquid crystal dimers, Liq.Cryst 28 (2001), pp.463-472.

[12] Hird.M, Tyone. K.J, and Gray.G.W, Day S.E and Mc. Donell D.G.(1993), Liq.Cryst.15, PP123.

[13] P.J.Collings and M.Hird (1997),Introduction of Liquid crystal chemistry and physics, Taylor and Fransis Ltd.U.K.1998.

[14] Marcos.M,Omenat.A,Serrano.J.L and Ezcurra.A(1992), Adv.Matter, 4,285.

[15] Hird M, Toyne K.J, Gray G. W. , Day S. E (1993) Liq. Cryst. 14, PP. 741.

[16] Doshi etal (i) D.M. Suthar and A.V.Doshi, Mol.Cryst.Liq.Cryst.Vol.575,PP.76-83.(ii) H.N.Chauhan and A.V.Doshi, Mol.Cryst.Liq.Cryst.Vol.570,PP.92-100 (2013) (iii)R.P. Chaudhari, M. L.Chahuan and A.V.Doshi, Vol 575, PP 88-95 (2013) (iv) U.C. Bhoya, N.N. Vyas and A.V.Doshi, Mol.cryst.Liq.Cryst.Vol.552.PP.104-110.(2012).

[17] D. Demuse, 100 Years of liquid crystal chemistry, mol.cryst.liq.cryst.165 (1988) PP.45-84.

[18] D. Demuse, Plenary lectures 100 years of liquid crystal chemistry, Thermotropic liquid crystals with conventional and unconventional molecular structures, Liq.Cryst,5 (1988) PP.75-110.

[19] C.T imrie and G.R.Luckhrust,"Liquid Dimers and Oligomers in handbook of Liquid crystal, law molecular liquid crystal; Vol. 2B, D.Demuse, J.W.Goodby, G.W.Graw, H.Spiess and V.Vill eds, Willey-VCH weinhe 1998,pp-801-833.

[20] D.M. Suthar, A.A.Doshi and A.V.Doshi. "Study of liquid crystalline state and evaluation of its properties through a novel Homologous series", Mol.cryst.Liq.Cryst.Vol.582, PP.79-87, 2013.

[21] Patel B.H \& Doshi A.V " synthesis and Liquid Crystal Properties of a Novel Homologous Series 4-(4`-n- Alkoxy benzoyloxy) Benzyl Benzoates” Mol.Cryst. Liq. Cryst. , Vol- 605, PP. 61-69. (2015).

[22] Patel B. H \& Doshi A.V “ Mesomorphism and Molecular Structure: Novel Homologous Series 4-(4`-n- Alkoxy cinnamoyloxy) - 4“'- methoxy Benzyl Benzoates” Mol.Cryst. Liq. Cryst. , Vol- 607, PP. 78-86. (2015). 
[23] (A) Rajesh B. Marathe, N.N. Vyas and Doshi A.V. “ Molecular Flexibility Operated Mesomorphism” ILCPA, Scipress Ltd, VOL-52. PP-163-171.(2015). (B) Ravindra Solanki and R.B Patel "Effect of Equipolar Endgroup of a Molecule on Mesomorphic-Isotropic Transition Curve" , ILCPA, Scipress,Vol.60(2015),pp.51-60. (C) N.R. Muniya, V.R. Patel “ Molecular Rigidity/ Flexibility Dependence of mesomorphism” ILCPA, vol.60 pp 120-128. (D) B.B.Jain and R.B. Patel, "Study of Thermotropic Mesomorphismin Nonlinear and Linear Isomeric and Nonisomeric Series", ILCPA, Scipress,Vol.60(2015),pp.1-10. (E) B.B. Jain and R.B. Patel' Study of Molecular Flexibility Operated Mesomorphism, ILCPA, Scipress,Vol.58 (2015), pp.16-25. (F) Vinay.S.Sharma and R.B. Patel,’Molecular Flexibility of Longer n-Alkoxy Tail Group Operated Mesomorphism”,ILCPA, Vol.59, PP.115-123, (2015). (G) Vinay.S.Sharma, R. B. Patel, "Study of Mesomorphism in Isomeric and Nonisomeric Linear and Nonlinear Chalconyl Series" ILCPA, Vol. 60 (2015), PP 182-191.

[24] Dave, J. S., \& Vora, R. A., (1970). Liquid Crystal and Ordered Fluids, Plenum Press:New York, Graw, G. W. (1958). Steric effect in conjugated systems. Ed., Butterworths, London, 477.

[25] Patel, R. B., Patel, V. R., \& Doshi, A. V. (2012). Mol. Cryst. Liq. Cryst., 552, 39.Chaudhary R. P., Doshi. A. V., Der Pharma Chemica 2012,4(3):1113-1119.

[26] Nagaveni, N.G., \& Prasad, V., (2013). "Azo substituted V-shaped liquid crystalline compounds: synthesis and mesophase characterization”, Phase Tran. 86, 12, 1227-1240.

[27] Doshi. A.V., Bhoya. U.C., and Travadi. J.J., "Determination of Transition Temperatures of Non mesomorphs by extrapolation method in binary systems "Mol. cryst. Liq.Cryst Vol.552, PP. 10-15,2012.

[28] Bhoya. U.C., Vyas. N.N., and Doshi. A.V., Determination of Latent Mesogenic behaviour in Nonmesogenic Compound by extrapolation"Mol.Cryst.Liq.Cryst.Vol552, PP.104110,2012 .

[29] K.J. Ganatra and A.V. Doshi, “ Study of Binary system including mesophase and determination of Letant Transition Temperature", Journal of Indian chem. Soc.,Vol. 77, july-2000, PP- 322-325.

[30] Lohar. J.M., and Doshi. A.V.," Study on mixed mesomoephism Determination of Latent transition Temperature(LTT) by extrapolation", Procedings of Indian Acad. Of Science Banglore,Vol.105, No-3,June1993PP.209-214.

[31] Solanki Ravindra, Sharma Vinay and Roshan Patel.entitled "Dependance of Thermotropic Mesomorphism on Molecular Flexible of Changing Tail Group." Manuscript Accepted in Mol. Cryst.Liq.Cryst. with its date of acceptance $22^{\text {nd }}$ may (2015) and its reference number LCMH-320,15 ${ }^{\text {th }}$ March(2015). 